Çocukluk Çağında Böbrek Apsesi: Beş Vakalık Bir Seri ve Literatürün Gözden Geçirilmesi

\title{
Renal Abscess in Childhood: Report of Five Cases and Review of Literature
}

Aysel Taktak, Fatma Şemsa Çaycı, Banu Acar, Nermin Uncu, Nilgün Çakar

Ankara Hematoloji Onkoloji, Çocuk Sağlığı Hastalıkları Eğitim ve Araştırma Hastanesi, Çocuk Nefroloji Bölümü, Ankara

\section{$\ddot{O} Z$}

Böbrek apsesi çocukluk çağında nadir görülür ve özgün belirtileri olmadığından tanıda güçlükler olabilir. Hastaların tanısında klinik, laboratuar ve görüntüleme yöntemleri yardımcıdır. Tanıyı takiben hızla antibiyotik tedavisi başlanmalıdır. Bazı olgularda perkütan ve/veya cerrahi drenaj, ciddi olgularda ise nefrektomi gerekebilir. Bu çalışmada böbrek apsesi olan 5 hasta tartışılmış ve literatür gözden geçirilmiştir.

\section{SUMMARY}

Renal abscess is uncommon in childhood and due to nonspecific clinical features there could be diagnostic difficulties. Clinical features, laboratory findings and imaging modalities are helpful in diagnosis. Subsequent to diagnosis, antibiotic treatment should be initiated promptly. In some cases percutaneous drainage or surgery is needed. In severe cases even nephrectomy is indicated. In this study, five patients with renal abscess are discussed and literature is reviewed.

Yayın hakları Güncel Pediatri'ye aittir. Sorumlu yazar yazışma adresi: Aysel TAKTAK. Ankara Hematoloji Onkoloji, Çocuk Sağlığı ve Hastalıkları 


\section{Giriş}

Böbrek apsesi, böbrek parankimi içerisinde kapsül ile çevrelenmiş enfeksiyon odağı olarak tanımlanır ve çocukluk çağında nadir görülür (1). Ateş ve karın ağrısı en sık görülen belirtilerdir, ancak bu belirtiler hastalığa özgü olmadığından tanıda güçlüklerle karşılaşılmaktadır (2). Kesin tanı üriner ultrasonografi (USG) ve bilgisayarlı tomografi (BT) ile konur (3). Tanısı konulan hastaların tedavisinde intra-venöz antibiyotikler ve apsenin, boyutları ve tedavi cevabına göre perkütanöz veya cerrahi olarak boşaltma yöntemleri uygulanır, nadiren hayatı tehdit eden vakalarda ise nefrektomi gerekebilir $(4,5)$. Bu çalışmada böbrek apsesi tanısı alan 5 hastamız tartışılmış ve konu ile ilgili literatür gözden geçirilmiştir.

\section{Gereç ve Yöntem}

Bu çalışmada Ocak 2008 ile Ocak 2016 tarihleri arasında Ankara Çocuk Sağlı̆̆ı ve Hastalıkları Hematoloji Onkoloji Eğitim ve Araştırma Hastanesi, Çocuk Nefroloji kliniğinde böbrek apsesi tanısı alan ve takip edilen 5 hasta geriye dönük olarak değerlendirildi. Tüm hastaların yaş, cinsiyet, başvuru şikâyeti, ateş ve fizik muayene bulguları, laboratuar verileri (tam kan sayımı, C-reaktif protein, sedimantasyon hızı, böbrek fonksiyon testleri), tam idrar tetkiki, idrar ve kan kültürü, apse ponksiyonu yapılan hastaların apse kültürü, tanısal görüntüleme sonuçları ve tedavileri kaydedildi.

\section{Bulgular}

Çalışmaya alınan hastaların 3'ü kız, 2'si erkek olup yaşları 16 ay ile 16 yıl arasında değişmekteydi. En sık başvuru şikâyeti karın ağrısı ve ateşti. Hastaların başvuru anında bakılan tam idrar tetkiklerinde değişen oranlarda piyüri mevcuttu. Tüm hastaların akut faz reaktanları yüksekti. Beyaz küre sayısı 13.800 ile $31.100 \mathrm{~mm}^{3}$ (normal değer:3600-9100 $\mathrm{mm}^{3}$ ), sedimantasyon hızı 43 ile $129 \mathrm{~mm} / \mathrm{saat}$ (normal değer:0-20 mm/saat), C-reaktif protein 8.6 ile $20.4 \mathrm{mg} / \mathrm{dl}$ (normal değer: 0-0.5 mg/dl) arasındaydı. Tüm olguların kan üre, kreatinin ve elektrolit düzeyleri normaldi.

Hastaların idrar kültür sonuçları incelendiğinde 1 hastanın idrar kültüründe üreme olmadığı, 2 hastada Escherichia coli (E. coli), bir hastada Proteus, bir hastada Staphylococcus aureus (S. aureus) üremesi olduğu görüldü.

Hastaların antibiyotik tedavisi öncesinde alınan kan kültürlerinde üreme olmadı, bir hastada apse ponksiyonu ile alınan püy kültüründe $S$. aureus üremesi oldu. Hastaların ilk başvurusunda yapılan üriner USG'de apse boyutları $3 \mathrm{~cm}$ altında saptandı. Bir hastada her iki böbrekte apse tespit edilirken diğer 4 hastada tek böbrekte apse vard1.

İki hastada üriner USG sonrası BT planlandı. BT planlanan bu hastalardan ilkinde üriner USG'de sağ böbrek üst kısımda 19x15 mm, sol böbrek üst, orta ve alt kısımlarında sırasıyla 10x6 mm, 10x7 mm ve 16x12 mm boyutlarında çok sayıda apse ile uyumlu görünüm mevcuttu. Bu hastanın batın BT'sinde 
karaciğer ve dalak normaldi, bilateral çok sayıda böbrek apsesi ile uyumlu oluşumlar gösterilmiş olup boyutları üriner USG ölçümleriyle uyumluydu. Batın BT yapılan ikinci hasta ise üretero-pelvik (UP) bileşke darlığı ve aynı böbrekte taş hastalığı nedeniyle takip edilmekteydi. Bu hastanın üriner USG'sinde, sağ böbreğinde 4. derece hidroüreteronefroz, tıkayıcı vasıfta olan, en büyüğü $8.5 \mathrm{~mm}$ olan birkaç adet taş, pelvikaliksiyel sistemde piyonefroz ve aynı taraf böbrekte 17x6 mm boyutlarında apse ile uyumlu görünüm tespit edilmişti, hastanın batın BT bulguları üriner USG ile uyumluydu.

Hastalar böbrek apsesine yatkınlık yaratacak nedenler açısından değerlendirildiğinde, bir hastada selektif IgA eksikliği, 2 hastada böbrek taşı olduğu görüldü. Hastaların böbrek taşlarının boyutları üriner USG'de sırasıyla, $8.5 \mathrm{~mm}$ ve $25 \mathrm{~mm}$ idi. Böbrek taşı $25 \mathrm{~mm}$ olan, bu yüzden tekrarlayan idrar yolu enfeksiyonu öyküsü olan hastanın üriner USG'sinde sağ böbrek 118x62 mm olup (yaşa göre teorik böbrek boyutu $80 \pm 6.6 \mathrm{~mm}$ ) görünüm ksantogranülomatoz nefrit ile uyumluydu.

Hastaların öyküsünde başvuru öncesinde antibiyotik kullanımı yoktu. Tüm hastalarda ampirik antibiyotik tedavisi seftriakson ve amikasin olmak üzere ikili antibiyotik rejimi olarak başlandı, tedavinin 72. saatinde akut faz reaktanları ve üriner USG tekrarlandı, yeterli tedavi yanıtı olmayan hastalarda antibiyotik tedavisi kültür hassasiyetine göre yeniden düzenlendi. Tüm hastalarda tedavi 4 haftaya tamamland1, 3 hastada tedavi bitimi 1 . ayda yapılan kontrol üriner USG'de apse görünümü kaybolmuştu. Ancak taş hastalığ 1 olan iki hastada üriner USG'de sebat eden böbrek parankim kalınlığında incelme, böbrek pelvisinde genişleme, ilgili böbrekte heterojen görünüm devam etmekteydi.

Beş hastaya takipte Tc-99m Dimercaptosuccinic asit (DMSA) ile böbrek sintigrafisi yapıldı. Beş hastanın ikisinde DMSA sintigrafisi normaldi, bir hastada apse bölgesiyle uyumlu alanda skar tespit edildi. Diğer iki hastadan ilkinde, üriner USG'si ksantogranülomatoz nefrit ile uyumlu olan hastamızda apse saptanan böbrekte fonksiyon olmadığ 1 görüldü, üretero-pelvik bileşke darlığı, tekrarlayan idrar yolu enfeksiyonu ve böbrek taşı ile takip edilen 2. hastada ise DMSA değerlendirmesinde sağ böbreğin total böbrek fonksiyonuna katkısı \%10'un altında saptandı. DMSA'ya göre total böbrek fonksiyonuna katılımı olmayan ve \%10'un altında olan bu iki hastaya, tekrarlayan idrar yolu enfeksiyonu öyküsü, taş hastalığı ve bu nedenle enfeksiyonlarının dirençli seyretmesi nedeniyle nefrektomi yapıldı. Hastaların demografik, klinik, laboratuar, görüntüleme bulguları ve tedavileri Tablo 1'de özetlenmiştir.

\section{Tartışma}

Çocukluk çağında böbrek apsesi nadir görülür ancak idrar yolu enfeksiyonunun önemli bir komplikasyonudur (6). Hastalık en sık ateş, bulantı, kusma, karın ve böğür ağrısı gibi özgün olmayan belirtiler gösterir iken, normal idrar bulgularının da tanıyı dışlamayacağı unutulmamalıdır (7). Böbrek apsesi; böbrek taşı, üriner sistemin yapısal anomalileri, immün yetmezlik gibi altta yatan kolaylaştırıcı nedenlere bağlı olabileceği gibi tamamen sağlıklı bireylerde de görülebilmektedir (8). Böbrek apseleri 
kortikal ve/veya kortikomedüller yerleşimde bulunabilir $(1,9)$. Kortikal yerleşimli böbrek apselerinde etken sıklıkla, primer bir bakteriyemi sonucu hematojen yayılım ile böbreğe ulaşan S. aureus'tur. Kortikomedüller yerleşimli böbrek apselerinde ise etken sıklıkla E. coli, daha az sıklıkla da Klebsiella, Proteus gibi diğer gram negatif bakterilerdir, bu hastalarda, vezikoüreteral reflü (VÜR) ve üriner sistemde tıkanıklığa neden olabilecek patolojilerin eşlik etme olasılığı daha yüksektir (10).

Literatür ile uyumlu olarak hastalarımızda ateş, karın ve/veya böğür ağrısı en sık rastlanan belirtilerdi, hastalar altta yatan kolaylaştırıcı faktörler açısından değerlendirildiğinde iki hastada böbrek taşı ve buna bağlı tekrarlayan idrar yolu enfeksiyonu öyküsü olduğu görüldü. Bir hastamızda ise selektif IgA eksikliği mevcuttu. Selektif IgA eksikliği çoğunlukla sino-pulmoner enfeksiyonlar, alerjik ve otoinflamatuar hastalıklar ile seyretmektedir. Selektif IgA eksikliğinde özellikle kapsüllü mikroorganizmalar olan Hemophilus influenza ve Streptococcus pneumonia enfeksiyon etkenidir. İdrar yolu enfeksiyonu ve tekrarlayan apse hastalığın mutat bulgularından değildir (11). Dolayısıyla bu hastamızda selektif IgA eksikliği kolaylaştırıcı bir sebep olarak kabul edilmedi. Üç hastamızda ise altta yatan kolaylaştırıcı bir neden tanımlanamadı. Böbrek apselerinde özgün olmayan klinik ve laboratuvar bulguları tanı konulmasını güçleştirse de görüntüleme yöntemleri tanıya yardımcıdır, tanıda ilk seçilecek görüntüleme yöntemi USG iken, seçilmiş olgularda BT tanının doğrulanmasında gereklidir (3). Böbrek apseleri, USG'de lokal sıvı seviyesi gösteren düşük ekojeniteli yer kaplayan lezyonlar iken, BT'de post kontrast tutulumlu kalın duvarlı iyi-tanımlı düşük dansiteli kitleler olarak tanımlanır (12).

Erken tanı ve antibiyotik tedavisi iyi bir klinik gidiş için gereklidir. En kısa sürede ampirik antibiyotik tedavisi E.coli, proteus, pseudomonas gibi Gram (-) mikroorganizma ve stafilokokları içine alacak şekilde planlanmalı ve tedaviye 3-6 hafta devam edilmelidir. Antibiyotik tedavisine ek olarak 3-5 cm üzerinde apsesi olan hastalarda ise perkütanöz veya açık drenaj uygulanmalıdır $(2,13)$.

Tedavisiz kalan böbrek apselerinin sepsis gibi ağır komplikasyonlara, böbrek fonksiyonlarında bozulmaya ve hatta hastanın kaybına neden olduğu bilinmektedir. Bu nedenle hayatı tehdit eden vakalarda nefrektomi gerekebilir (14). Berger ve arkadaşlarının 65 hastalık çalışmasında 16 hastada böbrek apsesi saptandığı ve ağır ürosepsis nedeniyle nefrektomi yapıldı̆̆ı, 3 hastanın ise kaybedildiği belirtilmiştir (15).

Çalışmamızda nefrektomi uygulanan ilk hasta UP darlık, eşlik eden taş hastalığı ve tekrarlayan dirençli idrar yolu enfeksiyonu nedeniyle izlenmekteydi. Hastanın DMSA sintigrafisinde etkilenen böbreğin total fonksiyona katılımı $<\% 10$ idi.

Nefrektomi yapılan 2. hasta, öyküsünden anlaşıldığı kadarıyla tekrarlayan idrar yolu enfeksiyonu geçiren, ancak takipsiz bir hasta idi. Üriner USG'si ksantogranülamatöz nefrit ile uyumluydu, DMSA sintigrafisinde sağ böbreğin fonksiyon görmediği belirlenerek nefrektomi kararı alındı. Böbreğin histopatolojik değerlendirme sonucu ksantogranülomatoz nefrit ile uyumluydu. 
Ksantogranülomatoz nefrit çoğunlukla erişkinlerde, özellikle 5. ve 6. dekatlarda görülür, çocuklarda nadirdir. Nedeni net olarak bilinmese de en sık neden tıkanmaya neden olan taşlardır. Hastalarda en sık etken E. coli ve hastamızda olduğu gibi Proteus 'dur (16). Çocukluk çağında özellikle enfeksiyon ilişkili nedenlerle radikal nefrektomi fazlaca kabul gören bir yöntem olmayıp çoğunlukla konservatif yöntemler tedavide esastır. Ancak nadiren özellikle takipsiz ve tedavisi geciken hastalarda nefrektomi zorunlu hale gelir. Ksantogranülomatoz nefritli olgularda lezyonlar erken dönemde fokal olabilir ve kısmı nefrektomi de bir tedavi seçeneği olabilir, ancak hastamızda ilgili böbrekte fonksiyon tamamen kaybedilmişti $(17,18)$.

Çocuk ve erişkin hastalarda nefrektomi endikasyonları farklılık gösterir, erişkin hastalarda en sık endikasyon böbrek maliniteleri iken çocuklarda, VÜR'dür. Hastalarda kronik enfeksiyon, taş hastalığı, üriner sistemde tıkanıklıklar, travmalar ve doğumsal displaziler nedeniyle geri dönüşsüz olarak hasarlanan böbreğin alınması standart ürolojik yaklaşımdır. Nefrektomi kararı temel olarak üriner USG ve DMSA ile verilir (19).

Sonuç olarak; tedaviye yeterli yanıtı olmayan ve dirençli seyreden idrar yolu enfeksiyonlarında, böbrek apsesi akılda tutulmalıdır. Erken tanı ve uygun tedavi ile hasta ve böbrek fonksiyonlarının kaybı önlenebileceğinden, tanıyı takiben geniş spektrumlu antibiyotik tedavisi başlanmalı ve altta yatan nedenler araştırılmalıdır. Antibiyotik tedavisine ek olarak, apse drenaj1 ve nadiren nefrektomi gibi cerrahi prosedürlerin de tedavinin önemli bir kısmını oluşturduğu unutulmamalıdır.

\section{Kaynakça}

1. Jaik NP, Sajuitha K, Sekar U, et al. Renal abscess. J AssocPhysiciansIndia 2006;54:241-3.

2. Steele BT, Petrou C, Maria J. Renal abscess in children. Urology 1990;36:325-8.

3. Cheng $\mathrm{CH}$, Tsai, MH, Su LH, et al. Renal abscessin children: A 10-year clinical and radiologicalexperience in a tertiarymedicalcenter. Pediatr Infect 2008;27:1025-7.

4. Lee SH, Jung HJ, Mah SY, Chung BH. Renal abscessesmeasuring $5 \mathrm{~cm}$ orless: Outcome of medicaltreatmentwithouttherapeuticdrainage. YonseiMed J 2010;54:569-73.

5. Canpolat N, Çalışkan S, Topal N, et al. Vezikoüreteral reflülü çocuk hastada Staphylococcus aureus'a bağlı kortikal yerleşimli böbrek apsesi. Çocuk Sağlığı ve Hastalıkları Dergisi 2008;51:165-7.

6. Wippermann CF, Schofer O, Beetz R, et al. Renal abscess in childhood: diagnostic and therapeuticprogress. Pediatr InfectDis J 1991; 10:446-50. 
7. Bayazıd AK, Noyan A, Tümgör G, Soyupak S, Anarat A. Çocukluk çağında böbrek absesi. TurkNeph Dial Transpl 2002;11:90-92.

8. Molino D, Anastasio P, Casoli E, et al. Renal abscess:recoverywithouthospitalization and drainage. ClinNephrol 2001;56:169-71.

9. Shimizu M, Katayama K, Kato E, et al. Evolution of acutebacterialnephritisinto a renal abscess. Pediatr Nephrol 2005;20:93-95.

10. Coelho RF, Schneider-Monteiro ED, Mesquita JL, et al. Renal and perinephriticabscesse: analysis of 65 consecutivecases. World J Surg 2007; 31: 431-6.

11. De Laat PCJ, Weermaes CMR, Gonnera R et al. Clinical manifestations in selective IgA deficiency in chilhood.ActaPaediatrScand 1991; 80: 798-804.

12. Angel C, Shu T, Green J, et al. Renal and peri-renal abscess in children: proposed physiopathologic mechanisms and treatment algorithm. Pediatr SurgInt 2003;19:35-39.

13. Barker AP, Ahmed S. Renal abscess in childhood. Aust N Z J Surg 1991;61:217-221.

14. Chabchoub K, Fakhfakh H, Kanoun S, Bahloul A, Mhiri MN. Childhood nephrectomy indications: a changing profile. Tunis Med 2010;88:474-7.

15. Berger I, Wildhofen S, Lee A, Ponholzer A, et al. Emergency nephrectomy due to severe ürosepsis: a retrospective, multicenter analysis of 65 cases. BJU Int 2009;104:386-90.

16. Chuang CK, Lai MK, Chang PL, et al. Xanthogranulamatous pyelonephritis: experience in 36 cases. J Urol 1992; 147:333-6.

17. Chabchoub K, Fakhfakh H, Kanoun S, Bahloul A, Mhiri MN. Childhood nephrectomy indications: a changing profile. Tunis Med 2010;88:474-7.

18. Diniz G, Aktaş S, Ortaç R, ve Ark. Pediatrikolgulardainfeksiyonlailişkilinefrektomilerinirdelenmesi ve ksantogranülomatoz piyelonefrit prevalansı. İzmir Dr. BehçetUz Çocuk Hast. Dergisi 2011;1:75-78.

19. Rafique M. Nephrectomy: indications, complications and mortality in 154 consecutive patients. J Pak Med Assoc 2007;57:308-11. 